
November 1999
-
NREL/SR-570-27541

\title{
The Value of the Benefits of U.S. Biomass Power
}

\author{
G. Morris \\ Green Power Institute \\ Berkeley, California
}



1617 Cole Boulevard

Golden, Colorado 80401-3393

NREL is a U.S. Department of Energy Laboratory

Operated by Midwest Research Institute $\bullet$ Battelle $\bullet$ Bechtel

Contract No. DE-AC36-99-G010337 


November 1999 $\ldots$ NREL/SR-570-27541
The Value of the Benefits of
U.S. Biomass Power

G. Morris

Green Power Institute

Berkeley, California

NREL Technical Monitor: R. Bain

Prepared under Subcontract No. AXE-9-18132

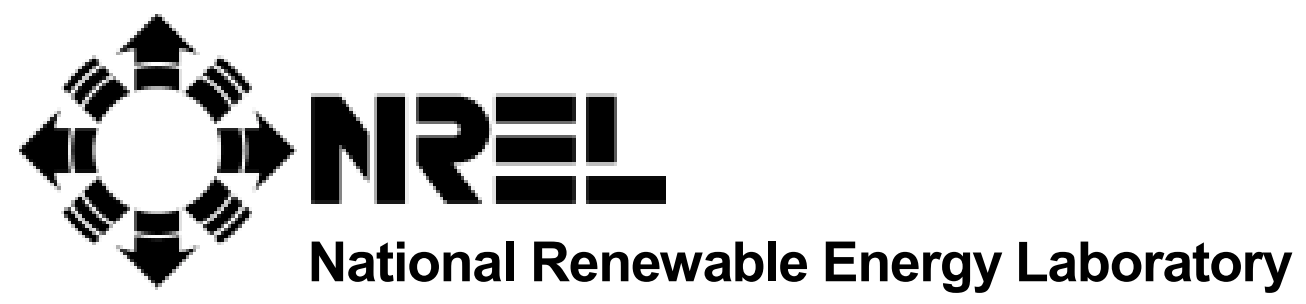

1617 Cole Boulevard

Golden, Colorado 80401-3393

NREL is a U.S. Department of Energy Laboratory

Operated by Midwest Research Institute • Battelle • Bechtel

Contract No. DE-AC36-99-G010337 


\section{NOTICE}

This report was prepared as an account of work sponsored by an agency of the United States government. Neither the United States government nor any agency thereof, nor any of their employees, makes any warranty, express or implied, or assumes any legal liability or responsibility for the accuracy, completeness, or usefulness of any information, apparatus, product, or process disclosed, or represents that its use would not infringe privately owned rights. Reference herein to any specific commercial product, process, or service by trade name, trademark, manufacturer, or otherwise does not necessarily constitute or imply its endorsement, recommendation, or favoring by the United States government or any agency thereof. The views and opinions of authors expressed herein do not necessarily state or reflect those of the United States government or any agency thereof.

Available electronically at http://www.doe.gov/bridge

Available for a processing fee to U.S. Department of Energy

and its contractors, in paper, from:

U.S. Department of Energy

Office of Scientific and Technical Information

P.O. Box 62

Oak Ridge, TN 37831-0062

phone: 865.576.8401

fax: 865.576.5728

email: reports@adonis.osti.gov

Available for sale to the public, in paper, from:

U.S. Department of Commerce

National Technical Information Service

5285 Port Royal Road

Springfield, VA 22161

phone: 800.553.6847

fax: 703.605.6900

email: orders@ntis.fedworld.gov

online ordering: http://www.ntis.gov/ordering.htm

Printed on paper containing at least $50 \%$ wastepaper, including $20 \%$ postconsumer waste 


\section{Executive Summary}

The U.S. biomass industry is at a crossroad. The contribution of biomass power generation is second only to that of hydropower among the renewables to the national energy supply. Biomass has always been used to generate power in the forest products industry, but its widespread use for supplying power to the U.S. grid is a relatively recent phenomenon, a response to the energy crises of the 1970s. Today independent biomass power generators supply 11 billion $\mathrm{kWh} / \mathrm{yr}$ to the national electricity grid and, in the process, provide an environmentally superior disposal service for 22 million tons/yr of solid waste.

The problem is that, in the current environment of cheap fossil fuel supplies and deregulation of the electric utility industry, biomass power generation may be unable to compete. The inherent cost of power generation from biomass is high for two principal reasons: (1) Biomass is a low-density fuel, so fuel production, handling, and transportation are more expensive than for fossil fuels; and (2) because of the dispersed nature of the resource, biomass power generating facilities tend to be small, so they cannot capture the economies of scale typical of fossil fuel-fired generating facilities. These characteristics leave biomass generation at a distinct disadvantage in a market that is increasingly driven by cost.

The great dilemma for public policy is that, although biomass power generation is expensive, it also provides very valuable waste disposal services that would be lost if the industry were to fail. Shrinkage of the industry in several regions during the past few years means that residues previously used for energy production are now being open burned or buried in landfills. Jurisdictions that have trouble meeting environmental mandates are finding their efforts at compliance completely trumped when they experience a drop in demand for biomass fuels.

This report describes an attempt to estimate the value of the ancillary services provided by biomass power generation, in order to provide policy makers with a yardstick against which to judge the cost of policy interventions that might preserve the viability of the biomass power industry. The following categories of impacts are considered:

- Criteria air pollutants

- Greenhouse gas emissions

- Landfill capacity use

- Forest and watershed improvement

- Rural employment and economic development

- Energy diversity and security

This report uses an analytical approach to compare the impacts of biomass energy production with that of alternative disposal of the residues, as well as of the alternative provision of the energy product. The principal alternative fates for biomass residues in the absence of energy production are open burning, landfill burial, and accumulation in forests. Approximately half the biomass fuels used by the independent biomass power industry in the United States today would be buried in landfills. Another third would be open burned. The remainder would be spread, composted, or remain as overstocked material in the forests.

Open burning of biomass residues produces massive emissions of smoke that contains particulates and other pollutants. Landfill burial of biomass residues accelerates the depletion of landfill capacity and leads to much higher emissions of greenhouse gases compared to controlled combustion of the material in power plants. Failure to thin and remove excess biomass from overgrown forests depresses forest health and productivity, increases risks of catastrophic wildfires, and degrades functioning of watersheds.

The environmental services provided by biomass power production are clearly valuable to society. Just how valuable, however, is not a simple question. The marketplace for environmental services provides 
some insights. The best market values available in the literature for criteria pollutants, greenhouse gases, landfill use, and mechanical thinning of forests are applied to the savings in these quantities associated with biomass energy production, allowing the calculation of a value for the environmental services provided, at least within the context of the categories included in the analysis. Based on a base-case, conservative analysis, the value of the environmental services associated with biomass energy production in the United States is $11.4 \phi / \mathrm{kWh}$. Moreover, this value includes none of the desirable benefits of rural employment, rural economic development, and energy diversity and security provided by biomass energy production.

A major contributor of value in the overall benefits calculation consists of greenhouse gas emissions. Greenhouse gas emissions are currently not regulated in the United States, and enacting programs to limit them is controversial. Counting greenhouse gas emissions at zero value leaves a residual value for the environmental benefits of biomass energy production for all other impact categories of $4.0 \notin / \mathrm{kWh}$. Taking minimum estimates for the values of all impact categories included in the analysis, the computed value of the nonelectric benefits of biomass energy is $4.7 \notin / \mathrm{kWh}$. Using a long-term perspective for the delayed emissions from landfills yields a calculated benefit value of $14.1 \phi / \mathrm{kWh}$.

Current experience in California with support payments in the amount of $1.5 \phi / \mathrm{kWh}$ shows that this level of support apparently provides the incentive needed for the continued operation of biomass energy facilities. However, the rest of the country has no such program, and the support program in California will be scaled back at the end of 1999, and eliminated two years later. The future of the industry may depend on the enactment of policies that provide tangible, ongoing compensation to biomass generators for the ancillary services they currently provide free of charge. The amount of compensation needed is only a small fraction of the value of the benefits preserved. Demonstrating that there will be a substantial net benefit to society from policies that preserve the viability of the biomass energy industry in the United States is easy. 


\section{Table of Contents}

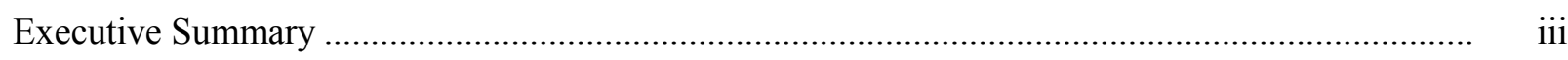

$1.0 \quad$ Introduction: Description of the U.S. Biomass Energy Industry................................... 1

2.0 Sources of Benefits: Alternatives for Biomass Residue Disposal .................................. 2

2.1 Biomass Fuel Use and Alternative Disposal Options ........................................ 2

2.1.1 Wood Processing Residues .................................................................... 4

2.1.2 In-Forest Residues.................................................................... 5

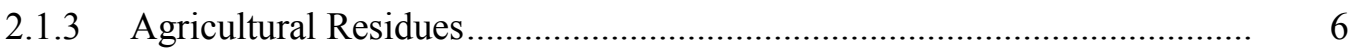

2.1.4 Urban Wood Residues.................................................................... 6

2.2 Environmental Impacts of Disposal Alternatives ............................................. 7

2.2.1 Environmental Impacts of Open Burning ................................................. 7

2.2.2 Environmental Impacts of Burial ........................................................... 8

2.2.3 Environmental Impacts of Spreading and Composting........................... 10

2.2.4 Environmental Impacts of In-Forest Accumulation.................................. 10

2.2.5 Environmental Impacts of Energy Production, Including
Fossil Fuel Alternatives................................................................... 11

2.3 Social Costs and Benefits of Disposal Alternatives ........................................... 12

2.3.1 Rural Employment and Taxes................................................................. 12

2.3.2 The Benefits of Energy Diversity and Domestic Supply ........................ 13

3.0 Value of Benefits: Estimates of the Dollar Value of Ancillary Services ............................ 14

3.1 Values of Environment Costs and Benefits................................................... 14

3.1.1 Value of Criteria Pollutants........................................................................ 14

3.1.2 Value of Greenhouse Gas Emissions ..................................................... 17

3.1.3 Value of Landfill Accumulation ................................................................ 17

3.1.4 Value of Forest Treatments ........................................................................ 17

3.2 Value of the Social Benefits of Biomass Power Production ............................................... 18

3.3 Calculated Value of the ancillary services of Biomass Power Production ......................... 18

3.4 Loss of Benefits: Consequences of a Shrinking Biomass Power Industry........................... 22



\section{List of Figures}

Figure 1 California Biomass Power Capacity .................................................................. 


\section{List of Tables}

Table 1 Alternative Fates for Biomass Fuels .....................................................................

$\begin{array}{lll}\text { Table } 2 & \text { Emissions Factors for Biomass Disposal Activities and Alternative Energy Production.. } & 9\end{array}$

Table 3 Emissions from Biomass Power Plants ..................................................................... 12

Table 4 Biomass Benefits ............................................................................................. 15

Table 5 Value of the environmental Benefits of the U.S. Biomass Energy Industry .................... 20

Table 6 Value of the Environmental Benefits of the U.S. Biomass Energy Industry ................... 21 


\subsection{Introduction: Description of the U.S. Biomass Energy Industry}

The biomass energy industry in the United States is one of the greatest, but least known, successes of the late 1970s. It enhances energy security and improves the environment. Biomass power plants today provide 2,410 MW of power to the national power grid, and an additional 5,035 MW of power directly to industrial energy users, particularly in the wood products industry. Biomass power generation consumes more than 100 million tons/yr of fuel, virtually all of which is waste or residue material that requires some form of treatment and disposal.

This report focuses on the segment of the biomass power industry that, because of changing conditions in the electric utility industry, is most vulnerable to extinction: the facilities outside the pulp and paper industry, and that generate power for distribution and sale through the interconnected electric utility grid. This segment consists of more than 100 operating biomass generation facilities in 23 states. These facilities provide $1,860 \mathrm{MW}$ of power generating capacity to the U.S. grid, and provide for the disposal of 22 million tons $/ \mathrm{yr}^{1}$ of waste and residue material. This segment would become eligible for the IRS Section 45 tax credit, should legislation currently under consideration by Congress be enacted into law.

This report presents the results of a study of the environmental and social benefits associated with biomass power production in the United States today. The approach involved conducting a literature search to identify the types and magnitudes of benefits provided by biomass power production, and the economic or dollar value of the benefits categories of interest. Readily available data were plugged into a model that computes the values of the identified and quantified benefits of biomass power production. The model traces the benefits from their sources, such as the avoided landfill disposal and avoided open burning of biomass residue materials. Avoided emissions, landfill use, and forestry improvements are quantified, and economic values are applied to the measures. Finally, the value of the alternative disposal activities is compared to the value of the energy option, allowing the value of the net cost or benefit of the energy pathway to be computed.

\footnotetext{
${ }^{1}$ Biomass fuels are sometimes reported in terms of green tons, and other times as bone dry ton (bdt) equivalents, which is a measure of the fiber content of the material. Green tons are used in the text of this report, except as indicated otherwise. Twenty-two million green tons/yr are equivalent to 11.9 million bdt/yr.
} 


\subsection{Sources of Benefits: Alternatives for Biomass Residue Disposal}

The biomass energy industry in the United States has always performed two separate and important functions: energy production and waste disposal. Each has important environmental implications. Energy production from biomass entails emissions during a variety of energy conversion processes, while avoiding the emissions associated with the production of a like amount of energy from fossil fuels. At the same time, disposal in biomass energy facilities avoids the environmental impacts associated with alternative disposal fates for the residues used as fuel, such as landfill burial or open burning. The latter effects constitute the most important source of environmental benefits associated with the production of energy from biomass resources.

\subsection{Biomass Fuel Use and Alternative Disposal Options}

The U.S. independent biomass energy industry ${ }^{2}$ today provides for the disposal of approximately 22 million tons/yr of solid biomass waste. Figure 1, for example, shows the history of biomass fuel use in California during the past 20 years, illustrating the rapid growth of biomass fuel use during the 1980s, followed by a decline during the mid-1990s. The pattern of biomass fuel use shown is typical of occurrences across the country.

The biomass residues used as power plant fuels come from a variety of sources, and would be subject to a variety of alternative fates if the biomass industry were not an available disposal option. The major categories of biomass fuels used in the United States today include:

- Wood processing residues

- In-forest residues

- Agricultural residues

- Urban wood residues

To account for the nonmarket societal costs and benefits of using biomass residues to produce energy, the impacts associated with energy production have to be compared with the consequences of the alternative fates the residues would experience in the absence of energy production. Thus, these fates must be characterized for the various residues and their associated impacts, as well as for the impacts of energy production, to determine the net environmental implications of biomass energy use.

In many regions of the United States the biomass energy industry has become an integral part of the solid waste disposal infrastructure. If the biomass industry were to fail, finding new disposal outlets for all the biomass residue material currently being used for fuel would be difficult. Identifying the probable alternative fates for these residues is also difficult. The major categories of alternative (nonenergy) disposal options for biomass residues include:

- Open burning of agricultural and forestry residues

- Landfill disposal of waste wood

- Composting and land application of waste wood

- Land spreading of wood chips and bark as mulch and cover

- In-forest accumulation of residues as downed and over-growth material

\footnotetext{
${ }^{2}$ This paper defines the independent biomass energy industry as that segment of the industry that is outside the pulp and paper industry, and that sells electricity into the grid-connected market.
} 





Open burning of biomass residues leads to heavy emissions of smoke and air pollutants. Landfill disposal of recyclable biomass accelerates landfill capacity depletion, and increases emissions of greenhouse gases. Composting and spreading also lead to higher greenhouse gas emissions than does energy production, and although growing rapidly, the markets for these materials are limited. In-forest accumulation of excess biomass residues degrades forest health, retards forest growth, diminishes watershed productivity, and increases the risk of destructive wildfires.

\subsubsection{Wood Processing Residues}

Wood processing residues constitute the most important biomass fuel source used in the United States, consistently accounting for more than $50 \%$ of the country's total biomass fuel supply. Almost half the biomass content of a typical sawlog becomes residue at a primary sawmill. A variety of secondary forest products applications have been developed to use a portion of this material. Active markets for wood processing residues in many regions include pulp chips, wood fiber for fiberboard and composites, animal bedding, and garden products such as decorative bark. Sawmills are used to segregating their residues into the highest-value markets available, but a substantial amount of the residues, typically $15 \%-20 \%$ of the biomass content of the sawlogs brought to a sawmill, have no useful application and must somehow be disposed. Biomass power plants have become the disposal option of choice for much of this material.

Wood processing residues come in a variety of forms, including:
- Bark
- Round-offs
- End cuts
- Trimmings
- Sawdust
- Shavings
- Reject lumber

The traditional method used to dispose of wood processing residues at sawmills was incineration in "teepee burners," a technology that produces copious amounts of smoke and other air pollutants. Beginning in the early 1970 s, air pollution control efforts applied increasing pressure on sawmills to close down their teepee burners, leading them to search for new disposal alternatives. This was an important factor that led to the development of the biomass power industry during the 1980s. In regions as diverse as California, Maine, and North Carolina, virtually all the readily available wood processing residues that have no higher-valued applications are used as power-plant fuel. Wood processing residues are the cheapest form of biomass fuel to produce and deliver. They would probably be the last type of biomass fuel to exit the system if the demand for biomass fuels were to decline.

Because of their severe air pollution problems, teepee burners have been largely eliminated as a disposal option for wood processing residues. The only readily available option for disposing of these materials, if fuel use were not a possibility, is landfilling. However, landfilling of waste wood is an undesirable option for a variety of reasons. Waste wood has a slower decay rate than other biomass forms, and is thus slow to stabilize in the landfill environment. It takes up $15 \%-20 \%$ percent of the space in a typical county landfill, and its decay leads to emissions of methane $\left(\mathrm{CH}_{4}\right)$, a more potent greenhouse gas than carbon dioxide $\left(\mathrm{CO}_{2}\right)$.

If the biomass energy industry were to collapse, a strong effort would probably be made to develop alternatives to landfilling. Nevertheless, for purposes of analysis, the probable alternative fate for most wood processing residues currently used for power production is landfill disposal. Some of the residues 
would probably be composted or land spread. Table 1 shows a breakdown of the probable alternative fates for wood processing residues in the absence of energy production, as well as other categories of biomass residues used for energy production in the United States.

Table 1: Alternative Fates for Biomass Fuels

\begin{tabular}{|c|c|c|c|c|c|}
\hline & Mill & Forest & $\underline{\mathrm{Ag}}$ & Urban & Total \\
\hline US Biomass Fuel Use (th.bdt/yr) & 6,400 & 1,800 & 2,300 & 1,400 & 11,900 \\
\hline Alternative Fate (\% of category) & Mill & Forest & $\underline{\mathrm{Ag}}$ & Urban & \\
\hline open burning & $\overline{5 \%}$ & $50 \%$ & $\overline{100 \%}$ & & \\
\hline landfill & $70 \%$ & & & $90 \%$ & \\
\hline composting & $10 \%$ & & & $10 \%$ & \\
\hline spreading & $15 \%$ & & & & \\
\hline forest accum. & & $50 \%$ & & & \\
\hline Alternative Fate (th.bdt/yr) & Mill & Forest & $\underline{\mathrm{Ag}}$ & $\underline{\text { Urban }}$ & $\underline{\text { Total }}$ \\
\hline open burning & $\overline{320}$ & 900 & $\overrightarrow{2,300}$ & - & $\overline{3,520}$ \\
\hline landfill & 4,480 & - & - & 1,260 & 5,740 \\
\hline composting & 640 & - & - & 140 & 780 \\
\hline spreading & 960 & - & - & - & 960 \\
\hline forest accum. & - & 900 & - & - & 900 \\
\hline
\end{tabular}

th.bdt $=$ thousands of bone-dry ton equivalents, which is a measure of the dry weight of biomass fuels

\subsubsection{In-Forest Residues}

In-forest residues constitute a major source of biomass fuels in the United States. Timber harvesting operations produce forest residues in the forms of slash (tops, limbs, bark, broken pieces) and cull trees. If left in place these residues are unsightly, impede forest regeneration, and increase the risk of forest fire. Increasingly, harvesting plans on public and private lands require some form of residue management, which usually means either piling and burning, or removal and use as fuel. Logging slash is an important source of biomass fuel in several regions.

In addition to logging residues, forest treatment residues (thinnings) comprise an important source of fuel for the biomass energy industry. Because of past forestry practices and aggressive fire-fighting efforts during the past 80-100 years, vast areas of American forests are overstocked with biomass material, which represents an increased risk of destructive wildfires and a generally degraded functioning of the forest ecosystems. These forests benefit greatly from mechanical thinning operations. The amount of inforest biomass residues that could be converted to energy is far greater than the total amount of biomass fuel demand in most regions of the country. However, this fuel source is generally more expensive to produce than other biomass fuels, so the quantity used is less.

As the market for biomass fuels has retracted in the United States, the amount of logging residues converted to fuel use has remained relatively constant, because of its link to the lumber market. The major adjustment has been in the quantities of thinnings being collected and converted to fuel. Most logging residues used for energy production would be pile burned, if energy applications were not available. On the other hand, forests would simply not be thinned, so material of this origin would accumulate as excess biomass. As shown in Table 1, this analysis assumes that $50 \%$ of the in-forest residues used for fuel would otherwise be pile-burned, and the other $50 \%$ would accumulate in the forest. 


\subsubsection{Agricultural Residues}

Agricultural operations produce large quantities of residues, which come in a wide variety of forms and consistencies. Agricultural residues suitable for use as power plant fuels include:

- Food processing residues such as pits, shells, and hulls

- Orchard and vineyard removals

- Orchard and vineyard prunings

- Field straws and stalks

Most of these residues require some form of treatment as a part of normal agricultural practice. In most cases the lowest-cost treatment option is open burning, a major source of smoke and air pollution. Avoiding agricultural burning is a principal reason biomass energy facilities have been developed.

In California, for example, approximately one-third of the biomass power plants were built in agricultural regions, and most are permitted on the basis of the state's agricultural offsets protocol, which provides air emissions offsets for pollutants that are avoided when biomass residues that would otherwise be open burned are used as fuel. During the 1990s agricultural fuels have consistently supplied about $20 \%$ of California's biomass fuel supply. More than 1 million tons/yr of agricultural residues are used as biomass fuel.

Most of the agricultural residues used as fuels in California are woody residues derived from the state's extensive orchard crops. Whole-tree chips produced from orchard removals constitute a particularly successful source of biomass fuel. Fuels are also produced from orchard prunings, vineyard removals and prunings, and other types of residues such as straws and food processing residues. Even with the present level of agricultural biomass fuel use in California, an enormous amount of agricultural residues suitable for use as power plant fuels continues to be open-burned. The alternative fate for the agricultural residues used for fuel is open burning (see Table 1), although a small percentage of these materials could be landfilled or plowed under.

\subsubsection{Urban Wood Residues}

As much as $15 \%-20 \%$ of the solid waste traditionally disposed of in U.S. landfills is clean wood waste that can be segregated and converted into power plant fuel. This material comes from a variety of sources, including:

- Construction and demolition wood waste

- Wood and brush from land clearing

- Wood and brush from public and private tree trimmers and landscapers

- Wood waste from the manufacturing of cabinets, furniture, and other wood products

- Discarded pallets and drayage

The traditional disposal option for urban wood waste is burial in landfills. However, the alternatives that might be used for this material in the future, should the fuels market disappear, are more complicated to project. For example, California's solid waste diversion law mandates that by the year 2000 all counties must achieve a diversion rate of $50 \%$ of their total solid waste, compared to their performance during the designated base year of 1990. An intermediate target of $25 \%$ diversion by 1995 was met statewide, but compliance with the year 2000 standards will be more difficult to achieve.

During the 1990s, landfill-diverted waste wood has supplied approximately 1.5 million tons of fuel annually to the California biomass power industry, hitting a peak of 1.9 million tons in 1993. As the 
overall biomass fuels market has declined, the percentage of landfill-diverted fuels in the state's biomass fuel mix has increased, from approximately $20 \%$ at the beginning of the decade, to $30 \%$ today.

Solid waste managers are under pressure to develop diversion applications of all kinds, and at least some of the material currently used as fuel would presumably be diverted into some other outlet, were it not used as fuel. For purposes of analysis, most of the waste wood currently diverted from landfills and converted into biomass fuel would otherwise be buried in the landfills. As shown on Table 1, 90\% of the urban biomass fuels would otherwise presumably be landfilled; the other $10 \%$ would be composted.

\subsection{Environmental Impacts of Disposal Alternatives}

All alternatives for the disposal of biomass wastes and residues, including leaving forest residues in place, entail environmental impacts. Energy production from biomass residues produces air pollutants and solid waste (ash), and consumes water resources. These impacts must be balanced against those impacts that would occur if the energy alternative were not available, including the impacts of alternate disposal of the material used as fuel, and the impacts of alternative production of the electricity that must be supplied to the market.

\subsubsection{Environmental Impacts of Open Burning}

Open burning of forestry and agricultural biomass residues is a major source of air pollution in many regions. Open burning produces massive amounts of visible smoke and particulates, and significant quantities of emissions of nitrogen oxides $\left(\mathrm{NO}_{\mathrm{x}}\right)$, carbon monoxide $(\mathrm{CO})$, and hydrocarbons that contribute to the formation of atmospheric ozone. Quantifying the emissions resulting from open burning is difficult because residues, burning practices, and environmental conditions are extremely variable. Nevertheless, use of these residues as power plant fuel vastly reduces the smoke and particulate emissions associated with their disposal, and significantly reduces the amounts of $\mathrm{CO}, \mathrm{NO}_{\mathrm{x}}$, and hydrocarbons released to the atmosphere.

Open residue burning is a particularly big problem in California's agricultural valleys, many of which are classified as nonattainment with respect to federal air quality standards for criteria pollutants.

Decreasing the amount of open burning of agricultural residues in California has long been an objective of air quality regulators, but the imperative for farmers to dispose of their residues cost effectively has prevented the banning of agricultural burning. The development of the biomass power industry during the 1980s helped mitigate the problem, but a great deal of residue continues to be open burned. At the peak of biomass fuel use in California from 1990 to 1993, more than 1.5 million tons/yr of agricultural residues were used as fuel. The decrease in biomass fuel use since 1993 has led to a decrease in the use of agricultural residue fuel. As a result, 0.5 million tons/yr of agricultural residues used as fuel as recently as 1993 are once again being disposed by open burning.

The state's air quality regulatory agencies recognized early that the biomass power industry could help eliminate open burning of agricultural residues. To give the biomass power producers credit for the air quality benefits they provide, regulators developed a set of agricultural offset protocols, through which facilities that burn agricultural residues that would otherwise be open burned earn an offset for their emissions of pollutants at the power plant. Because emission offsets are required only for pollutants for which the receiving basin is nonattainment, most agricultural offsets have been for emissions of $\mathrm{NO}_{\mathrm{x}}$ and particulates. For most facilities that were permitted on the basis of the agricultural offset protocols, the permits require that one-half to two-thirds of their fuel be obtained from agricultural residue sources. 
One of the largest efforts to measure the emissions of open burning of biomass was undertaken by researchers at the University of California, Riverside (Darley 1979). The emission factors reported from this study were used as the basis for developing agricultural offset protocols, and remain the best, albeit limited, source of data on emissions from the open burning of biomass. AP-42, the U.S. Environmental Protection Agency's (EPA) compilation of air pollution emissions from a variety of industrial activities, uses the Darley data and other sources to characterize the emissions typical of open burning of a variety of biomass residues, under various conditions. Table 2 shows emissions estimates for open burning of biomass residues under various conditions, as well as emissions factors for other activities described in the following sections.

\subsubsection{Environmental Impacts of Burial}

Recoverable wood waste represents approximately $15 \%$ by weight, and as much as $20 \%$ by volume, of the material that typically enters sanitary landfills. All these materials enter the landfill gate separate from mixed household garbage.

Separable wood residues enter the landfill in debris boxes, roll-off bins, vans, and pickup trucks. In the absence of a fuel-use option, they are buried along with other wastes entering the landfill gate. Some landfills segregate and shred inbound waste wood to use as daily landfill cover or for other applications, but this represents a small fraction of the total recoverable resource, and these applications would be unlikely to expand significantly if the fuel market collapsed. Indeed, there is reason to believe that nonfuel applications would actually decline if the fuel market collapsed, because the production of these products in most cases depends on the coproduction of fuel, and loss of the fuel market would render production of the other products less viable.

Landfill burial of the wood residues that can be recovered and converted into power plant fuel entails the same kinds of environmental impacts associated with the disposal of all kinds of organic wastes in landfills. Compared to other types of organic wastes, woody materials are slow to degrade, which means that landfill stabilization is delayed. Like all organic material in the landfill, waste wood can be a source of water-polluting leachates, and as the material degrades, it produces emissions of $\mathrm{CH}_{4}$ and $\mathrm{CO}_{2}$ in roughly equal quantities. Methane and $\mathrm{CO}_{2}$ are both greenhouse gases, but $\mathrm{CH}_{4}$ is much more reactive, by a factor of some 25 times per unit of carbon (IPCC 1996), so emissions of the residue-bound carbon in the form of a 50:50 mix of $\mathrm{CH}_{4}$ and $\mathrm{CO}_{2}$, rather than as pure $\mathrm{CO}_{2}$, are far more damaging from the perspective of greenhouse gas buildup in the atmosphere (Morris 1992).

Large landfills are now required by EPA regulations to control their fugitive emissions by collecting a portion of the landfill gas and flaring it. For example, approximately $60 \%$ of the landfills in California, which receive $80 \%-95 \%$ of the state's solid waste, are covered by this regulation. In general, gas collection systems capture about $80 \%$ of the $\mathrm{CH}_{4}$ released by the landfill, which means that final emissions of the waste carbon to the atmosphere are approximately $90 \% \mathrm{CO}_{2}$ and $10 \% \mathrm{CH}_{4}$ (compared with approximately 50:50 for an uncontrolled landfill). Emitting the carbon in the 90:10 mixture of $\mathrm{CO}_{2}$ and $\mathrm{CH}_{4}$ results in an effective greenhouse gas emission 3.4 times more potent than emissions of the same amount of carbon in the form of $100 \% \mathrm{CO}_{2}$. For uncontrolled landfills, the 50:50 mixture of the gases emitted leads to an effective greenhouse gas emission 13 times more potent than emissions of the same amount of carbon in the form of $100 \% \mathrm{CO}_{2}$. The only effective means of eliminating $\mathrm{CH}_{4}$ emissions from the disposal of wood residues that would otherwise be buried in a landfill is to use the material as fuel. Table 2 shows emissions factors for burial of waste wood in landfills.

Use of waste wood as a fuel results in immediate emissions of $\mathrm{CO}_{2}$; burial of the material in a landfill results in delayed emissions of $\mathrm{CO}_{2}$ and $\mathrm{CH}_{4}$. Wood waste decays slowly in the landfill environment, so emissions of most ultimate landfill gases are significantly delayed. This should be taken into account in 
Table 2: Emissions Factors for Biomass Disposal Activities and Alternative Energy Production

\begin{tabular}{|c|c|c|c|c|c|c|c|c|c|}
\hline & $\begin{array}{c}\mathrm{SO}_{\mathrm{x}} \\
\text { (lb/th.bdt) }\end{array}$ & $\begin{array}{c}\mathrm{NO}_{\mathrm{x}} \\
\text { (lb/th.bdt) }\end{array}$ & $\begin{array}{l}\text { particulate } \\
\text { (lb/th.bdt) }\end{array}$ & $\begin{array}{c}\text { CO } \\
\text { (lb/th.bdt) }\end{array}$ & $\begin{array}{c}\mathrm{CH}_{4} \\
\text { (lb/th.bdt) }\end{array}$ & $\begin{array}{c}\text { nmHCs } \\
\text { (lb/th.bdt) }\end{array}$ & $\begin{array}{c}\mathrm{CO}_{2} \\
\text { (ton/th.bdt) }\end{array}$ & $\begin{array}{c}\text { landfill } \\
\left(\mathrm{m}^{3} / \text { th.bdt }\right)\end{array}$ & $\begin{array}{c}\text { thinned } \\
\text { (acres/th.bdt) }\end{array}$ \\
\hline biomass energy * & 150 & 2,500 & 450 & 7,500 & 250 & 25 & 1,780 & 24.2 & \\
\hline open burning & 150 & 7,000 & 15,000 & 150,000 & 8,000 & 24,000 & 1,690 & & \\
\hline landfill & & & & & 430,000 & & 1,200 & 2,400 & \\
\hline $\begin{array}{l}\text { composting-- } \\
\text { immediate }\end{array}$ & & & & & 33,000 & & 850 & & \\
\hline composting--delayed & & & & & 65,000 & & 800 & & \\
\hline spreading & & & & & 130,000 & & 1,600 & & \\
\hline forest accum. & 150 & 7,000 & 21,000 & 280,000 & 7,000 & 23,000 & 1,690 & & 40 \\
\hline coal (unit/mmkWh) & 3,500 & 3,100 & 140 & 960 & 15 & 290 & 1,100 & 43.9 & \\
\hline gas/st (unit/mmkWh) & 6 & 270 & 80 & 910 & 25 & 60 & 600 & & \\
\hline gas/cc (unit/mmkWh) & 5 & 85 & 330 & 860 & 130 & 60 & 450 & & \\
\hline
\end{tabular}

${ }^{*}$ Note that for biomass energy production, unit/th.bdt is approximately the same as unit/mil.kWh) 
an analysis that compares the two options. The immediate result of diverting landfill-bound waste wood to a power plant is that virtually all the carbon content is added to the atmospheric stock of $\mathrm{CO}_{2}$, rather than being stored underground as buried waste. This means that the atmospheric greenhouse gas burden associated with the biomass residue used as fuel is greater in the immediate aftermath of its combustion than if the material were landfilled. Over time, however, the landfill out-gases a mixture of $\mathrm{CH}_{4}$ and $\mathrm{CO}_{2}$, and the much greater radiative effectiveness of $\mathrm{CH}_{4}$ rapidly leads to a greater greenhouse gas burden, which eventually becomes a major liability for the landfill option, even with the use of gascontrol systems on landfills.

\subsubsection{Environmental Impacts of Spreading and Composting}

An alternative disposal option to landfilling biomass wastes is surface spreading, which can be done with or without prior composting of the material. Bark and wood chips can be used directly for mulch, which usually consists of open spreading of the untreated material. Biomass can also be composted before spreading, although woody material is not ideal for composting, because it breaks down more slowly than other types of biomass residues, such as residential green waste.

Composting of biomass residues accelerates the natural decomposition process. Decomposition occurs through aerobic and anaerobic pathways, producing a mixture of $\mathrm{CO}_{2}$ and $\mathrm{CH}_{4}$ emissions. In a wellmanaged compost operation the emissions are primarily $\mathrm{CO}_{2}$, because of frequent aeration of the material. The compost product, which contains approximately $50 \%$ of the original biomass carbon, is then spread, where it continues to decompose, although no longer at an accelerated pace. Table 2 shows estimates of the greenhouse gas emissions associated with composting and/or spreading of biomass residues.

\subsubsection{Environmental Impacts of In-Forest Accumulation}

All forests are prone to periodic fires. However, the natural fire cycle has been altered in many regions of the United States by past forestry practices, by vigorous fire suppression efforts, and by increasing populations in wooded areas. These phenomena have increased the amount of fuel loading and degraded forest health and productivity (see, for example, Cal. Dept. of Forestry 1996).

The fuel building up in the nation's forests includes standing dead and diseased wood, downed woody material of all varieties, and an overall increase in the density of the forest growing stock. The accumulation of dead and diseased wood, both standing and downed, is particularly problematic from a forest fire risk perspective because it usually has a lower moisture content than growing stock, making it easier to ignite, hotter burning, and more prone to spreading of fire. As the fuel loading continues to increase, fires that burn out of control tend to be much more severe and destructive than the naturally occurring periodic fires that were a component of the pre-industrial ecosystem. They burn much hotter than the traditional fires, and consume much larger areas with more extensive destruction. Table 2 shows estimates of the emissions associated with forest fires in overstocked forest conditions.

Fuel overloading also contributes to the degradation of the health and ecosystem functioning of forests and watersheds. For example, healthy, relatively undisturbed forest ecosystems in California have approximately a $40 \%$ level of canopy closure, whereas other forests have an approximately $60 \%-65 \%$ or more canopy closure level. This elevated level means that the amount of available rainfall that enters the evapotranspiration cycle is higher than in the native ecosystem, and less of the rainfall moves through the watershed as runoff and groundwater. Reduced flows of runoff and groundwater mean that less water is transferred to the meadows and lowlands, where water is stored during the rainy season and released gradually during the dry season. 
The net result of this chain of events is that useful water production from many watersheds is lower than if the forests were in a more natural condition. This includes water for human consumption, and environmental water available for river and delta ecosystems. An effective, sustained thinning program in key watersheds could increase useful water supplies without further development of water supply infrastructures. Several experimental programs are underway to prove this connection, and to provide data on the amounts of water production that will result from thinning and other watershed improvement operations (Cal. Dept. of Water Resources 1994). A great deal of work remains to be done to understand the relationship between watershed improvement activities and the rate of water production from the treated watershed.

\subsubsection{Environmental Impacts of Energy Production, Including Fossil Fuel Alternatives}

Combustion of biomass fuels in modern power plants leads to many of the same kinds of emissions as the combustion of fossil fuels, including criteria air pollutants, greenhouse gases, and solid wastes (ash). Fuel processing, which in most cases involves some type of grinding operation, produces emissions of dust and particulates. Air emissions and water consumption are usually the principal sources of environmental concern related to biomass facilities.

Biomass power plants are required to achieve stringent emissions control levels for the criteria, or regulated, pollutants. These include particulates, $\mathrm{NO}_{\mathrm{x}}$, oxides of sulfur $\left(\mathrm{SO}_{\mathrm{x}}\right)$, hydrocarbons, and $\mathrm{CO}$. $\mathrm{NO}_{\mathrm{x}}$, hydrocarbons, and $\mathrm{CO}$ are usually controlled by using advanced combustion technologies, often including fluidized-bed combustors, staged-combustion, and flue-gas recirculation. Some of the newest biomass power facilities are required to use ammonia injection to further control $\mathrm{NO}_{\mathrm{x}}$ emissions. $\mathrm{SO}_{\mathrm{x}}$ emissions generally are not a concern with biomass combustion because biomass, especially woody forms of biomass, has a very low sulfur content. Some facilities that have fluidized-bed combustors inject limestone to capture sulfur, but no biomass facilities are required to have flue-gas scrubbers to control $\mathrm{SO}_{\mathrm{x}}$ emissions.

Particulates are controlled using a variety of technologies. Virtually all biomass power plants use cyclones to remove most large particulates from the flue gas. Most biomass facilities are equipped with electrostatic precipitators for final particulate removal; some facilities use baghouses. Most modern biomass power plants are required to achieve zero visible emissions to meet environmental permit conditions. Their emissions of total and sub-micron particulates are also regulated and controlled to stringent levels, comparable to or better than the emissions levels achieved by the large fossil fuel power plants operated by the electric utility companies.

Table 3 shows average emissions levels of the criteria pollutants for biomass power generation. The data are based on information supplied by 34 California biomass facilities, and include permitted emissions levels and actual source test data. The data are further differentiated by combustor type. Eleven of the 34 facilities have fluidized-bed combustors; the other 23 have grate-burners of various designs. The fluidized-bed combustors achieve lower emissions levels of all criteria pollutants of concern for biomass power plants, compared to the grate burners. The most dramatic difference is in $\mathrm{CO}$ emissions, for which the fluidized-bed combustors are more than an order of magnitude better than the grate-burners. The fluidized-bed combustors achieve emissions factors of half or less than the grate-burners for all pollutants for which data are available. 
Table 3: Emissions from Biomass Power Plants

\begin{tabular}{lrrrrrr}
\hline & \multicolumn{3}{c}{ Permit Levels } & \multicolumn{3}{c}{ Measured Emissions } \\
\hline & All & Grates & FBs & All & Grates & FBs \\
\hline $\mathrm{NO}_{\mathrm{x}}$ & 2.6 & 3.1 & 1.5 & 2.0 & 2.5 & 1.0 \\
$\mathrm{SO}_{\mathrm{x}}$ & 1.2 & 0.9 & 1.7 & 0.1 & $\mathrm{NA}$ & 0.1 \\
$\mathrm{CO}$ & 11.5 & 16.3 & 2.0 & 10.3 & 14.7 & 0.2 \\
$\mathrm{HCs}$ & 1.7 & 1.8 & 1.6 & 0.5 & 0.7 & 0.1 \\
Particulates & 0.8 & 1.0 & 0.6 & 0.5 & 0.6 & 0.3 \\
\hline
\end{tabular}

Data averaged for 34 California biomass facilities, 23 Grates, 11 fluidized-bed burners.

The production of electricity in biomass power plants helps reduce air pollution by displacing the production of power using conventional sources. There is considerable geographic variability, but the marginal generating source displaced by biomass generation in most cases in the United States is either natural gas-fired power generation or coal-fired power generation. The full net emissions reductions associated with biomass power generation can be calculated as the difference between the net emissions associated with the biomass power cycle alone, and those that would be produced by fossil fuel-based generation, which would be used if the biomass-generated power were not available. Table 2 shows emissions factors for fossil fuel-fired electricity production, based on AP-42 and other sources. These data include only the emissions at the power plant, not those associated with producing and processing the fuels.

\subsection{Social Costs and Benefits of Disposal Alternatives}

In addition to the environmental benefits of energy production from biomass fuels, biomass energy production provides important social and economic benefits to rural areas. These include high-quality jobs, the generation of local and regional tax revenues, and energy diversity and supply security for regional and national energy systems.

\subsubsection{Rural Employment and Taxes}

The specific nature of a biomass power plant's fuel supply is the primary determinant of both its design and location. Because most facilities use significant components of agricultural or forestry residuals, most are located in rural areas dominated by resource-based economies. These communities are often characterized by slow economic growth rates and high unemployment. Biomass power facilities mean jobs with good comparative wages. Power plant employees receive attractive benefits packages, and in many cases support workers engaged in fuel-production operations do as well. Support jobs are generated at a ratio of almost 2:1 compared to plant employment, with total employment equal to 4.9 fulltime jobs per each megawatt of net plant generating capacity. The long-term nature of this employment provides durable improvement and added stability to the local and regional economies surrounding the plants.

Biomass power plants also make important contributions to the tax base of many rural communities. In many cases biomass power plants are the largest single property tax payers in their respective jurisdictions. The facilities also generate income taxes and sales taxes from their employees and from the workers that support them. 


\subsubsection{The Benefits of Energy Diversity and Domestic Supply}

Although more than two decades have passed since the oil embargoes of the 1970s, the United States remains energy-deficit, importing nearly $60 \%$ of its petroleum. In the event of a major supply disruption, electricity generation could be severely affected. Additionally, the present concentration of large power plants at grid centers in urban areas makes power supply vulnerable to both natural and human-caused destruction. The scale and dispersion of biomass energy facilities, and their renewable fuel supply in primarily rural areas, provide a low probability of grid-related or human-caused failure. Indeed, during the heat-related brownouts of 1996 in California, all biomass plants remained online while many large utility plants reduced load or went offline completely.

The biomass power industry also contributes to the potential of biomass energy use in general, in all its possible manifestations. The federal government has invested a significant amount of money and effort to develop new technologies and applications for biomass energy, including advanced electricity generating technologies and liquid fuel technologies. Many projections of energy supplies for the United States envision an increasing role for biomass. The future of biomass energy production, whatever direction it might take, will inevitably be built on the foundation of the industry that has already been created. 


\subsection{Value of Benefits: Estimates of the Dollar Value of Ancillary Services}

Conversion of biomass wastes and residues to energy provides great environmental benefits by reducing the amount of air pollution, greenhouse gas emissions, and landfill use associated with their disposal, by promoting healthier forests, contributing to rural economies, and displacing the use of fossil fuels. Placing monetary values on these environmental and social benefits is more difficult. This study uses literature values for the dollar value of various environmental impact categories, and applies them to the impacts of biomass energy production, and the activities it avoids. The net value of biomass energy production is calculated as the difference between the costs of the impacts of energy production, and the costs of the alternative disposal options and alternative power provision.

\subsection{Values of Environment Costs and Benefits}

This analysis focuses on the environmental benefits of the current biomass power industry, and their quantification. Because of uncertainties in assigning dollar values to the various impact categories, ranges of values that encompass current economic thinking on the subject, observed and forecast market values, and the effects of current regulations and economic conditions, are presented in Table 4. Most are transaction values based on "cap and trade" systems. They represent societal values for marginal reductions in emissions, assuming that society has correctly determined an optimal "cap" for the emissions. Evidence suggests that there is still substantial damage, mortality, and morbidity at the current capped levels. In such a case, these market values represent a "floor" value of the benefits of marginally reducing emissions. The real societal values may well be higher.

Many of the air pollutants shown in Table 4 have multiple values because there are different prices for these emissions in different markets. Prices are generally higher in more densely populated areas, and often vary from one region to another. The appropriate prices must be used when quantifying the value of current biomass generation. There may be one value for substitute generation located near load centers in urban areas, and another for disposal of the biomass that would have been consumed in generally rural facilities. For analytical purposes, the same values are used throughout for each given impact category. This represents conservatism in the analysis.

\subsubsection{Value of Criteria Pollutants}

$\underline{\mathrm{SO}}_{\mathrm{x}}$ : There is a wide and active trading market for sulfur dioxide $\left(\mathrm{SO}_{2}\right)$ emissions because of the EPA Acid Rain Program. Prices tend to be stable and uniform, signs of a maturing market. The values in Table 4 are indicative of current prices for trades. They are almost double the prices of a year ago, and reflect Phase II of the Acid Rain Program. They represent good long-term societal values for analytical purposes.

$\underline{N O}_{x}: \mathrm{NO}_{\mathrm{x}}$ values vary more than other criteria pollutants. Prices vary by location and season. These differences should be considered when determining the benefit/cost of reducing or increasing $\mathrm{NO}_{x}$ emissions. This means that the cost of increases in $\mathrm{NO}_{\mathrm{x}}$ emissions associated with substitute generation near populated load centers may be greater per unit than the cost of increases in $\mathrm{NO}_{\mathrm{x}}$ emissions for disposal of wood waste as power plant fuel in a rural environment. $\mathrm{NO}_{\mathrm{x}}$ values cannot be varied, Cantor Fitzgerald Environmental Brokerage Services average national price index for $\mathrm{NO}_{\mathrm{x}}$ can be used. 
Table 4. Biomass Benefits

\begin{tabular}{|c|c|c|c|}
\hline Category & $\begin{array}{l}\text { Value }(1999 \$, \\
1^{\text {st }} \text { quarter) }\end{array}$ & Source & Comments \\
\hline $\mathrm{SO}_{2}$ & \$206-\$212/ton & $\begin{array}{l}\text { Market prices for the first half of } 1999 \\
\text { reported by brokerage firms and the } \\
\text { Fieldston Publications market survey } \\
\text { as reported by the EPA Acid Rain } \\
\text { Program. }\end{array}$ & $\begin{array}{l}\text { These prices are indicative of } \\
\text { current prices for trades. They } \\
\text { are almost double the price a } \\
\text { year ago and reflect Phase II of } \\
\text { the Acid Rain Program. They } \\
\text { are better long-term prices than } \\
\text { those of a year ago. }\end{array}$ \\
\hline NO $_{x}$ & $\begin{array}{l}\text { Cantor Fitzgerald } \\
\text { Market Price: } \\
2000-\$ 2,100 / \text { ton } \\
2000-02-\$ 2,018 / \text { ton } \\
\text { New England: } \\
\text { Ozone Season - } \\
\$ 1000-1,050 / \text { tpy } \\
\text { Non-Ozone - } \$ 650- \\
700 / \text { tpy } \\
\text { Mid Atlantic (NY, PA) } \\
\text { Severe - } \$ 5,000 / \text { tpy } \\
\text { Moderate - } \$ 2,000 / \text { tpy } \\
\text { California (ERCs): } \\
\text { San Joaquin Valley - } \\
\$ 9,733 / \text { tpy } \\
\text { Bay Area - } \$ 6,500 / \text { tpy }\end{array}$ & $\begin{array}{l}\text { Cantor Fitzgerald Environmental } \\
\text { Brokerage Services }\end{array}$ & $\begin{array}{l}\text { NOx prices vary quite a bit } \\
\text { regionally, and by time of year. } \\
\text { Values are generally higher in } \\
\text { the California, urban areas and } \\
\text { during the summer. The C-F } \\
\text { Market Price is a good } \\
\text { compromise for a single value, } \\
\text { but regional values should be } \\
\text { used, with lower values for rural } \\
\text { areas (unless rural area is a } \\
\text { non-attainment area, i.e., } \\
\text { California). }\end{array}$ \\
\hline $\mathrm{CO}_{2}$ & $\begin{array}{l}\text { Current Transactions: } \\
\$ 0.45-\$ 1.81 / \text { ton } \mathrm{CO}_{2} \\
\text { SGM (Administration) } \\
\$ 7.74-\$ 41.47 / \text { ton } \mathrm{CO}_{2} \\
\text { EIA/NEMS }(2010 \\
\text { Price): } \\
\$ 18.94-\$ 83.10 / \text { ton } \mathrm{CO}_{2} \\
\text { Markel-Macro Model } \\
\text { (2010 Price): } \\
\$ 25.01-\$ 41.74 / \text { ton } \mathrm{CO}_{2}\end{array}$ & $\begin{array}{l}\text { Cantor Fitzgerald Environmental } \\
\text { Brokerage Services } \\
\text { Unfinished Business: The Economics } \\
\text { of the Kyoto Protocol, Battelle PNL, } \\
7 / 98 \text { (draft) } \\
\text { Impacts of the Kyoto Protocol on U.S. } \\
\text { Energy Markets and Economic } \\
\text { Activity, EIA, 10/98 } \\
\text { Climate Change Economic Analysis: } \\
\text { Technical Annex, Interagency Analytic } \\
\text { Team, } 7 / 97\end{array}$ & $\begin{array}{l}\text { Current transaction price } \\
\text { represents current trades being } \\
\text { undertaken for risk } \\
\text { management purposes in the } \\
\text { absence of U.S. ratification of } \\
\text { the Kyoto Protocol. } \\
\\
\text { The model runs are for the } \\
\text { prices in } 2010 \text {. The low values } \\
\text { assume unlimited international } \\
\text { trading, the high values } \\
\text { assume no international } \\
\text { trading. }\end{array}$ \\
\hline Methane & $\begin{array}{l}\text { Current Transactions: } \\
\$ 31-\$ 124 / \text { ton } \mathrm{CH}_{4} \\
\text { Model Forecasts }(2010 \\
\text { Price): } \\
\$ 532-\$ 5,700 / \text { ton } \mathrm{CH}_{4}\end{array}$ & & $\begin{array}{l}\text { Methane values are } \mathrm{CO}_{2} \text { values } \\
\text { multiplied by } 25, \text { the } \\
\text { instantaneous global warming } \\
\text { potential for methane. }\end{array}$ \\
\hline
\end{tabular}




\begin{tabular}{|c|c|c|c|}
\hline VOC & $\begin{array}{l}\text { California ERCs: } \\
\text { San Joaquin Valley - } \\
\$ 3,600 / \text { tpy } \\
\text { Bay Area - \$5,500/tpy } \\
\text { Maryland ERCs: } \\
\$ 2,500 / \text { tpy } \\
\text { New York/Pennsylvania } \\
\text { ERCs: } \\
\text { Severe - } \$ 2,000 / \text { tpy } \\
\text { Moderate - } \$ 1,850 / \text { tpy } \\
\text { Massachusetts ERCs: } \\
\$ 3,000 / \text { tpy }\end{array}$ & $\begin{array}{l}\text { Cantor Fitzgerald Environmental } \\
\text { Brokerage Services }\end{array}$ & $\begin{array}{l}\text { The values for non-methane } \\
\text { hydrocarbons (volatile organic } \\
\text { compounds [VOCs]) vary } \\
\text { significantly from region to } \\
\text { region. In rural areas the } \\
\text { values tend to be lower. } \\
\text { Values also tend to be lower in } \\
\text { the East than in the West, and } \\
\text { lower in the Mid-Atlantic than in } \\
\text { New England. }\end{array}$ \\
\hline Particulate & $\begin{array}{l}\text { Rural: } \$ 1,050 / 1,000 \\
\text { lbs. } \\
\text { Urban: } \$ 1,506 / 1,000 \\
\text { lbs. }\end{array}$ & $\begin{array}{l}\text { Environmental Costs of Electricity, } \\
\text { Pace University Center for } \\
\text { Environmental Legal Studies, } 1990\end{array}$ & $\begin{array}{l}\text { The values are based on PM- } \\
\text { 10. Rural values are for } \\
\text { visibility and the Urban values } \\
\text { include visibility and } \\
\text { mortality/morbidity. }\end{array}$ \\
\hline $\mathrm{CO}$ & $\begin{array}{l}\text { Current Transactions: } \\
\$ 0.71-2.84 / \text { ton CO } \\
\text { Model Forecasts ( } 2010 \\
\text { Price): } \\
\$ 12.16-130.59 / \text { ton CO }\end{array}$ & & $\begin{array}{l}\text { The values are based on the } \\
\text { equivalent greenhouse gas } \\
\text { value on a per-carbon basis to } \\
\mathrm{CO}_{2} \text {. }\end{array}$ \\
\hline Landfill & $\begin{array}{l}\$ 15.06 / \text { ton - } \\
\$ 29.94 / \text { ton }\end{array}$ & $\begin{array}{l}\text { Full Cost Accounting in Action: Case } \\
\text { Studies of Six Solid Waste } \\
\text { Management Agencies, USEPA, } \\
\text { 12/98 }\end{array}$ & $\begin{array}{l}\text { Landfill costs vary by site, an } \\
\text { average of } \$ 22.00 / \text { ton. Seems } \\
\text { to be reasonable. The values } \\
\text { here are fully allocated costs, } \\
\text { including capital, financing and } \\
\text { O\&M. }\end{array}$ \\
\hline $\begin{array}{l}\text { Forest } \\
\text { Productivity }\end{array}$ & $\$ 125-\$ 650 /$ acre & $\begin{array}{l}\text { Recent studies by Jolley \& Carlson, } \\
\text { and Morris (see references) }\end{array}$ & \\
\hline
\end{tabular}

Particulates: Most recent literature on particulates focuses on smaller particles of 10 microns or smaller (the most recent literature focuses on particles smaller than 2.5 microns). Open burning of biomass waste creates many particles larger than 10 microns; controlled burning tends to release small particles.

The values in the table are based on PM-10. Rural values are for visibility degradation and the urban values include visibility degradation and increases in mortality/morbidity.

CO: A review of the literature indicates that $\mathrm{CO}$ pollution reduction is primarily of value in a limited number of urban "hot spots," and that reductions in rural releases of $\mathrm{CO}$, through a reduction in open burning, had little or no value to the environment. There has been a significant reduction in the ambient levels of CO during the past two decades, primarily through improvements in the environmental performance of automobiles. This improvement has diminished the value of further reductions in $\mathrm{CO}$ emissions from stationary sources.

Carbon monoxide in the atmosphere has a greenhouse gas warming potential roughly equal to that of $\mathrm{CO}_{2}$ (see Value of Greenhouse Gas Emissions), and in fact the ultimate fate of atmospheric CO is oxidation to $\mathrm{CO}_{2}$. Thus, at a minimum, the value of $\mathrm{CO}$ emissions is equivalent, on a per-carbon basis, to the value assumed for $\mathrm{CO}_{2}$ emissions. 
Non-methane hydrocarbons: The values for non-methane hydrocarbons (volatile organic compounds [VOCs]) vary significantly from region to region. In rural areas the values tend to be lower. Values also tend to be lower in the East than in the West, and lower in the Mid-Atlantic than in New England.

\subsubsection{Value of Greenhouse Gas Emissions}

$\mathrm{CO}_{2}$ : The market for $\mathrm{CO}_{2}$ emissions trading is in its infancy. Trades executed so far have been voluntary, not pushed by regulatory compliance requirements. These transactions have been conducted at very low prices, $\$ 0.45-\$ 1.81 /$ ton of $\mathrm{CO}_{2},(\$ 1.83-\$ 7.33 /$ metric ton of carbon equivalent). The current transaction price represents trades being undertaken for risk management purposes in the absence of U.S. ratification of the Kyoto Protocol. If the Kyoto Protocol is ratified, prices are expected to increase dramatically. Price forecasts vary substantially, based mostly on the amount of trading assumed in the forecast. Prices vary from a low of approximately \$7.74/ton $\mathrm{CO}_{2}$ in the Clinton Administration's analysis (assuming widespread and unlimited international trading), to $\$ 83.10 /$ ton $\mathrm{CO}_{2}$ in the analysis done by the Energy Information Administration, U.S. Department of Energy, at the request of Congress (assuming very little trading). An average of the two, $\$ 45.42 /$ ton $\mathrm{CO}_{2}$ is close to the upper end of the Interagency Analytic Team's (IAT) forecast. For analytical purposes, a value of $\$ 33 /$ ton $\mathrm{CO}_{2}$ is used for the base-case data set, which is the average of the IAT forecasts.

$\underline{\mathrm{CH}}_{4}$ : Methane has an instantaneous global warming potential 25 times greater than $\mathrm{CO}_{2}$ on a per-carbon basis (IPCC 1996). However, the residence time of $\mathrm{CH}_{4}$ in the atmosphere is much shorter than that of $\mathrm{CO}_{2}$, so in the long term the difference in warming potential between the two gases decreases. The IPCC recommends using a value of 20.4 for a 20 -year time perspective, and 7.6 for a 100 -year time perspective. The model developed for this study calculates a value of 15.8 for a 20 -year time perspective, and 6.8 for a 100-year time perspective, which is slightly more conservative than the IPCC recommendations.

\subsubsection{Value of Landfill Accumulation}

The values for reductions in the amount of landfill used resulting from diversion of waste wood to energy production is based on the fully allocated costs of current landfills. It does not represent the cost to open a new landfill (the long-term marginal cost of waste disposal in a landfill), and so is a lower bound on the value of benefits of reduced landfill use caused by current biomass capacity. However, the cost includes the cost of EPA regulations to capture and dispose of landfill $\mathrm{CH}_{4}$.

\subsubsection{Value of Forest Treatments}

The literature on the value of forest treatment activities is sparse, but a recent paper (Jolley and Carlson 1999) provides a useful measure, which can be defined as the saving in ultimate cost, on a net-present value basis, of using mechanical thinning for forest treatment versus a regime of prescribed burns that must be carried out over a number of years to achieve the same degree of forest improvement.

The mechanical thinning regime, followed 5 years later by a prescribed burn, has a cost (npv) of $\$ 432 /$ acre. The alternative of three prescribed fire treatments during a 20 -year period has a cost (npv) of $\$ 560 /$ acre, for a net saving of $\$ 128 /$ acre using the mechanical thinning and fuel-production alternative. This sets a lower limit on the marginal value of the mechanical thinning alternative. It does not credit the thinning alternative for its reduction in ultimate air emissions during the various burns, for its reduction in residual stand damage, and for the fact that the benefits of fuels reduction are achieved immediately with the mechanical thinning/fuel production option, while the benefits are achieved over a 20 -year period with the prescribed burning alternative. 
Another recent study (Morris 1998), which takes into account factors such as long-term timber stand values and reductions in fire-fighting costs, calculates a net benefit of mechanical thinning operations in the range of $\$ 200-\$ 650$ per acre treated. A mid-point value of $\$ 400 /$ acre is used in the model as the base-case value.

\subsection{Value of the Social Benefits of Biomass Power Production}

The social benefits of biomass power production, such as the generation of rural employment and economic development, and energy diversity and security, are even more difficult than the environmental benefits to quantify and value. Thus, no values are included in the model for social benefits, although they are significant and valuable. The following discussion illustrates the magnitude of the tax benefits that are provided by biomass power plants.

Based on an average annual income of $\$ 35,500$ (not including benefits or employer-paid taxes), and 4.9 workers per MW of installed capacity, biomass power plant employees and support workers generate $\$ 26,200$ in federal income tax, and $\$ 8,700$ in state income tax, for each megawatt of operating biomass electric generating capacity. Local and personal sales taxes are not included.

Property tax, based on a rate of $1 \%$ of assessed valuation, equates to $\$ 8,900 / \mathrm{MW}$ power plants plus $\$ 1,400 / \mathrm{MW}$ for fuel supply infrastructure and related equipment. In addition, based on average taxable purchases of supplies, parts, and equipment of $\$ 28,000 / \mathrm{MW}$, sales tax at $7 \%$ yields an additional $\$ 2,000 / \mathrm{MW}$ annually. The total tax revenue generated from biomass energy production is approximately $\$ 47,200 / \mathrm{MW}$ power produced per year. This translates into a total tax contribution of $\$ 88$ million in the United States annually that is attributable to the independent biomass energy industry.

\subsection{Calculated Value of the Ancillary Services of Biomass Power Production}

A model has been constructed to compute the value of the identified ancillary services provided by biomass power production. The model begins with an accounting of the types and quantities of fuels used by the independent biomass power industry in the United States today. This inventory is based on an updated database of operating U.S. biomass power facilities maintained by the principal author of this report. The industry provides for the disposal of 22 million tons of biomass residues annually. More than half the total fuel supply is composed of sawmill residues; the remainder is distributed among the categories of in-forest residues, agricultural residues, and urban waste wood. The first page of the model's printout, shown on Table 5, shows the amounts of biomass residues used as power-plant fuels. (Fuel use values in the model are presented in bdt, not green tons.)

Assumptions about the alternatives fates of the various residues, if they were not used as fuels (Table 1), are applied to the fuel use data to determine the avoided disposal pathways for which the biomass energy industry provides. Almost half the residues would be landfilled in the absence of energy production, about one-third would be open burned, and the remainder would be composted or spread, or represent an accumulation of overstocked material in the nation's forests.

Emissions factors and other environmental measures (Table 2) are applied to the alternative disposal activities to compute the magnitude of the emissions and other measures for biomass energy production, and for all the activities it avoids. This computation is shown on the second page of the model's printout (Table 6). The magnitudes of the values are then summed across the categories, and the two alternatives, biomass energy production versus biomass residue disposal and fossil-fuel energy production, are compared. 
For analytical purposes, a conservative base-case data set was selected. Some base-case data, such as fuel use data, assumptions about alternative fates for the biomass, impacts, and impact values, were discussed earlier. Several additional assumptions, shown in the lower half of Table 5, are worthy of discussion. In the base case $40 \%$ of the power displaced, at the margin, by the current level of biomass power generation is assumed to be coal, and the remainder is natural gas. This is a conservative assumption, as more than $50 \%$ of power in the United States is generated from coal, and biomass often competes with base-load generating sources, of which coal is an example.

The base case also uses a 20 -year timeframe for the analysis, and counts only the delayed emissions of landfill disposal and other alternatives during the first 20 years after use. For landfills, for example, in which waste wood is conservatively assumed to have a half-life of 30 years, only $37 \%$ of the ultimate emissions are counted. The base-case half-lives for landfilled waste wood and residues accumulating in forests are both conservatively chosen to be long.

As shown in Tables 5 and 6, using conservative base-case values for all the identified impact categories, the value for the ancillary environmental benefits of biomass energy production is calculated as $\$ 1.2$ billion/yr, or $11.4 \notin / \mathrm{kWh}$ of electricity produced from biomass. This represents an average for all the biomass fuel used by the independent biomass power industry in the United States. This calculated value covers only the categories of impacts included in the analysis, and excludes the economic and social benefits of biomass energy production discussed previously.

Using the base-case data set, the computed value of using each of the four types of biomass residues varies within the range of 7.8 (in-forest residues) to $14.0 \notin / \mathrm{kWh}$ (urban waste wood). Residues that would otherwise be open burned provide a benefit of $8.9 \mathrm{c} / \mathrm{kWh}$ if used for energy production. Residues diverted from landfill disposal provide a benefit of $14.9 \mathrm{c} / \mathrm{kWh}$ when used for energy production. Residues left as overstocking in the forest provide a benefit of $6.7 \phi / \mathrm{kWh}$ if used for energy production.

The dollar value for each impact category is reported in the literature as a range of values (Table 4). Values for many of the categories have rather broad ranges of uncertainty. Running the model with minimum values for all categories produces a benefit value of $4.7 \phi / \mathrm{kWh}$ for biomass energy production. Using maximum values for all the categories, the benefit value is $24.7 \phi / \mathrm{kWh}$.

A significant contributor to the computed value of these biomass energy benefits is the value of avoided greenhouse gas emissions. Greenhouse gases are not regulated in current practice; hence, there is no established market value for them. The international Kyoto protocols, (in the process of ratification by countries around the world) require reductions in greenhouse gas emissions, which would establish a market and value for these materials. Assuming a zero value for greenhouse gases leaves a residual value for the other computed benefits of biomass energy production with the base-case data set of $4.0 \notin / \mathrm{kWh}$. Estimating the value of avoided greenhouse gas emissions is complicated by the timeframe used to judge the delayed emissions of $\mathrm{CH}_{4}$ and $\mathrm{CO}_{2}$ from landfills, the disposal alternative for $48 \%$ of the biomass fuels used in the United States today. The base case includes all emissions released over a 20 -year period following the use or burial of the biomass fuels. A long-term time perspective, for example using a 75year timeframe, increases the calculated benefits with otherwise base-case assumptions to $14.1 \notin / \mathrm{kWh}$. 
Table 5. Value of the Environmental Benefits of the U.S. Biomass Energy Industry

Fuel Use (th.bdt/yr)

Alternative Fate (\%)

open burning

landfill

composting

spreading

forest accumulation

Alternative Fate (th.bdt/yr) open burning

landfill

composting

spreading

forest accumulation

\begin{tabular}{|rlrr|}
\multicolumn{1}{r}{ Mill } & Forest & Ag & Urban \\
\hline 6,400 & 1,800 & 2,300 & 1,400 \\
\hline & & & \\
\hline $5 \%$ & $50 \%$ & $100 \%$ & $90 \%$ \\
$70 \%$ & & & $10 \%$ \\
$10 \%$ & & & \\
\hline
\end{tabular}

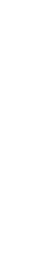

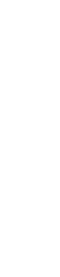

$\begin{array}{rccccc}320 & & & & \text { Total } & \\ 4,480 & 900 & 2,300 & - & 3,520 & 30 \% \\ 640 & - & - & 1,260 & 5,740 & 48 \% \\ 960 & - & - & 140 & 780 & 7 \% \\ - & - & - & - & 960 & 8 \% \\ & 900 & - & - & 900 & 8 \%\end{array}$

Total Fuel Use

Electric Generation Effic.

Electricity Produced



$\%$ of displaced electricity that would have been supplied by

Coal

Natural Gas / Steam Turbine

Natural Gas / Combined Cycle



Delayed Emissions Factors

Years of Delayed Emissions

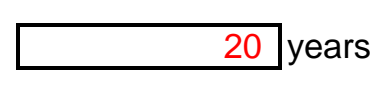
landfill
composting
spreading
forest accumulation

\begin{tabular}{|c|}
$1 / 2$ Life in Storage \\
\hline 30 \\
2.5 \\
2.5 \\
35 \\
\hline
\end{tabular}

Multiplier

2.00 
Table 6. Value of the Environmental Benefits of the US Biomass Energy Industry

Ultimate Impacts (unit/th.bdt) unit

VS

biomass energy

open burning

landfill

composting--immediate

composting--delayed

spreading

forest accum.

coal (unit/mmkWh)

gas/st (unit/mmkWh)

gas/cc (unit/mmkWh)

\begin{tabular}{|c|c|c|c|c|c|c|c|c|}
\hline sox & $\mathrm{NOx}$ & particulate & $\mathrm{CO}$ & $\mathrm{CH}_{4}$ & $\mathrm{nmHCs}$ & $\mathrm{CO}_{2}$ & landfill & thinned \\
\hline $\mathrm{lb}$ & $\mathrm{lb}$ & $\mathrm{lb}$ & $\mathrm{lb}$ & $\mathrm{lb}$ & $\mathrm{lb}$ & ton & $\mathrm{m} 3$ & acres \\
\hline 150 & 2,500 & 450 & 7,500 & 250 & 25 & 1,780 & 24.2 & \\
\hline 150 & 7,000 & 15,000 & 150,000 & 8,000 & 24,000 & 1,690 & & \\
\hline & & & & 430,000 & & 1,200 & 2,400 & \\
\hline & & & & 33,000 & & 850 & & \\
\hline & & & & 65,000 & & 800 & & \\
\hline & & & & 130,000 & & 1,600 & & \\
\hline 150 & 7,000 & 21,000 & 280,000 & 7,000 & 23,000 & 1,690 & & 40 \\
\hline 3,500 & 3,100 & 140 & 960 & 15 & 290 & 1,100 & 43.9 & \\
\hline 6 & 270 & 80 & 910 & 25 & 60 & 600 & & \\
\hline 5 & 85 & 330 & 860 & 130 & 60 & 450 & & \\
\hline
\end{tabular}

Impacts

open burning

landfill

composting

$\underline{N}$

spreading

forest accum

coal

gas/st

gas/c

VS

Total, no energy

biomass energy

Value of Impacts

(approx. mid points)

Value (th. $\$ / y r$ )

biomass energy

no biomass energy

Net Biomass Benefit (th. $\$ / \mathrm{yr}$ )

Benefit in $\mathrm{c} / \mathrm{kWh}$

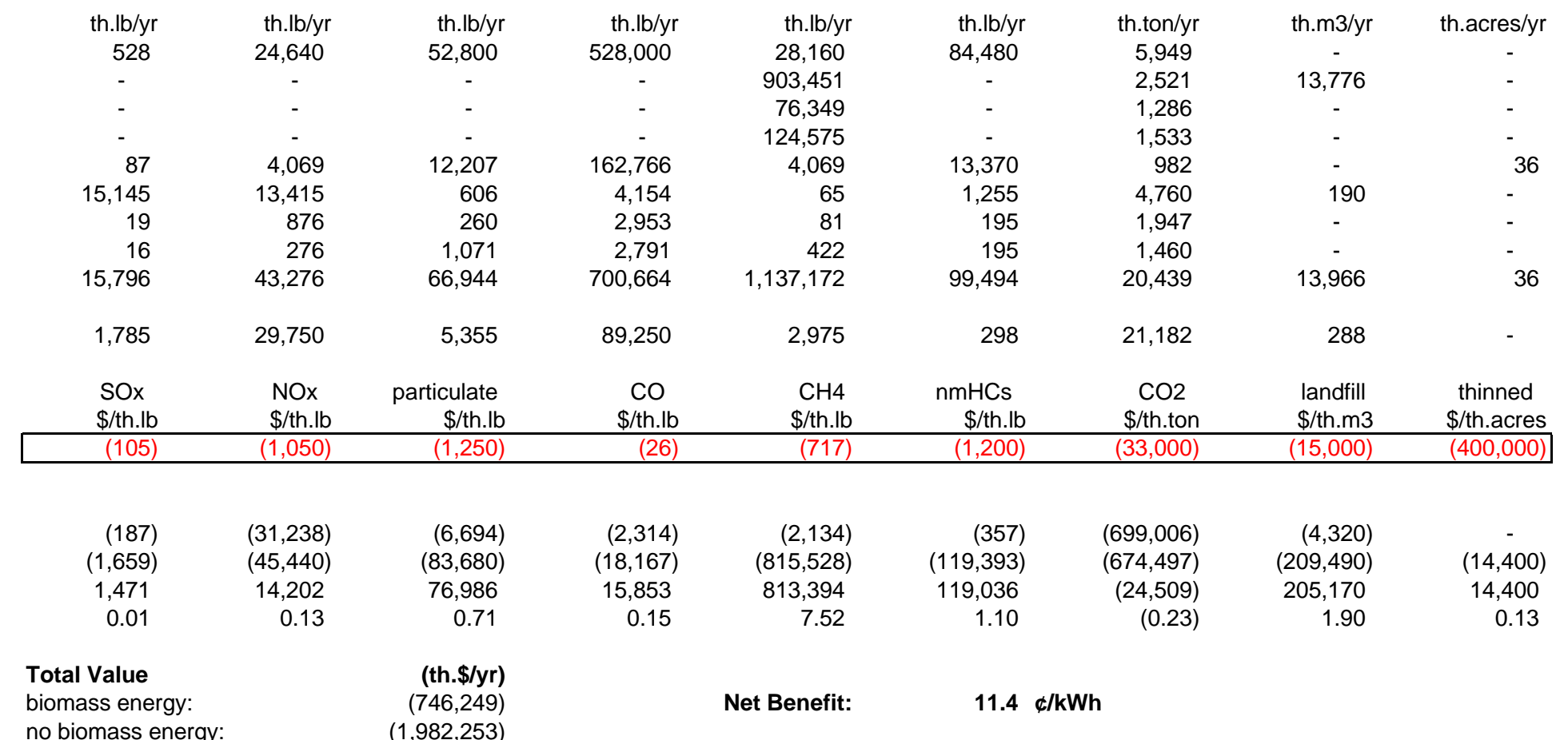

(data in boxes are inputs to the model) 


\subsection{Loss of Benefits: Consequences of a Shrinking Biomass Power Industry}

The independent biomass power industry in the United States reached its peak level of production around 1990 , and has since declined by more than $25 \%$. This decline has a variety of causes, many of which are regional, but the underlying reality is that biomass energy is expensive to produce, compared to the lowest-cost alternatives available on the grid. The high cost of biomass power production, an inevitable result of the small size of the facilities and the high cost of collecting and transporting low-density residue materials, is a considerable liability in a market that is deregulating and increasingly emphasizing cost. The future viability of the enterprise is in doubt.

Any further decline in biomass energy production in the United States, whether caused by facility closures or to cutbacks in operations by the operating facilities, leads directly to a loss in the amount of environmental and social benefits provided by the industry. As demonstrated earlier, based on a conservative base-case set of assumptions, the value for the quantifiable benefits is $11.4 \phi / \mathrm{kWh}$ of electricity produced from biomass. The identified social benefits not included in the computation are also significant, and add to the total societal value. These are very impressive numbers, much higher than the current market value of the energy, which is in the range of $2-3 \phi / \mathrm{kWh}$ in most regions. Even using minimal values for all quantified impacts, and ignoring the nonquantifiable ones, the benefits of biomass power production $(4.7 \mathrm{c} / \mathrm{kWh})$ are much higher than the level of support necessary to preserve the enterprise. The expected societal return on support for biomass power production is a multiplicative factor of 7.6. And this value includes only selected environmental impacts for which data are available.

Disappearance of the biomass energy industry in the United States would present serious social and environmental consequences for the regions that would be most affected. More than 5 million tons/yr of residues currently used as fuel would be added to the burden of material entering sanitary landfills, further burdening the capacity problem, making compliance with landfill diversion statutes in many regions virtually impossible, and loading the country with future greenhouse gas emissions that will not be avoidable when greenhouse gas emissions reduction mandates must be achieved.

Disappearance of the industry would mean that 4.6 million tons of residues currently being used as fuels will return to open burning piles, where they will add measurably to air pollution problems in affected agricultural and forested regions, many of which are already out of compliance with air quality standards. An additional 1.6 million tons/yr of residues will be allowed to accumulate in overstocked or otherwise unhealthy forests and watersheds. These residues will exacerbate the risks of destructive wildfires and ecosystem degradation.

The loss of the biomass energy industry would represent a loss of almost 12,000 rural employment positions, with serious impacts in affected regions. Many rural communities would also lose their largest source of property taxes, and would suffer other multiplier effects. Energy diversity and security values would be lost.

The loss of the U.S. biomass energy industry would exacerbate a number of important environmental problems, and leave affected rural regions with virtually irreplaceable losses of quality employment opportunities and tax base. In fact, increasing the capacity use of the current infrastructure, and encouraging the development of new biomass installations using ever-advancing technology, should be important goals of national and regional energy policy. The ancillary benefits of biomass power production are worth far more than its above-market costs. A modest level of compensation for these benefits will achieve a several-fold return in social and environmental benefits. The California experience with the payment of biomass production credits in the amount of $1.5 \notin / \mathrm{kWh}$ demonstrates that 
this level of support can achieve stabilization and increased facilities to use. A higher level of support probably would be needed to encourage the development of new biomass energy production capacity.

Biomass energy production provides two valuable services to society: it is the second most important source of renewable energy currently being produced in the United States, and it is an important component of the nation's solid-waste disposal infrastructure. In the old world of high energy prices, sales of electricity alone were sufficient to pay for the entire enterprise. In the current world of low energy prices and increasing competition, electricity revenues cannot support the continuing operation of biomass energy facilities. Unless a mechanism is developed to compensate biomass generators for the ancillary services they provide, these services will be lost. This report demonstrates that the easily quantifiable environmental benefits of biomass energy production, using conservative assumptions, are worth 7.6 times more than the amount of support needed to sustain it. When social benefits and more difficult to quantify environmental benefits are added to the equation, the societal return on support for biomass energy production is even greater. 


\subsection{References}

California Department of Forestry, California Fire Plan: A Framework for Minimizing Costs and Losses from Wildland Fires, March 1996.

California Department of Water Resources, Bulletin 160-93, California Water Plan Update, October 1994.

Ellis Darley, Hydrocarbon Characterization of Agricultural Waste Burning, Cal/ARB Project A7-06830, University of California, Riverside, April, 1979.

Houghton, Filho, Callander, Harris, Kattenberg, \& Maskell, Eds., Climate Change 1995: The Science of Climate Change, Intergovernmental Panel on Climate Change, Cambridge University Press, 1996.

Steve Jolley and Bill Carlson, Prescribed Fire Alone vs. Mechanized Pre-Fire Treatments: A Case for Considering all the Tools, Report by Wheelabrator Environmental Systems, Spring 1999.

Gregory Morris, Greenhouse Gas Emissions from Waste Wood Disposal, Report by Future Resources Associates, Berkeley, CA, May 11, 1992.

Gregory Morris, The Environmental Costs and Benefits of Biomass Energy Use in California, NREL report NREL/SR-430-22765, May 1997.

Gregory Morris, White Paper: The Economic Implications of Energy Production from Forest Residuals, Report of the Green Power Institute, Berkeley, CA, October 19, 1998.

U.S. Environmental Protection Agency, Compilation of Air Pollutant Emission Factors AP-42, Fifth Edition, Volume I: Stationary Point and Area Sources, Report of the U.S. Environmental Protection Agency, Washington, DC, last updated April 1999. 


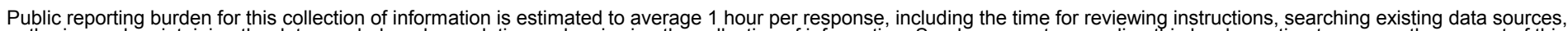

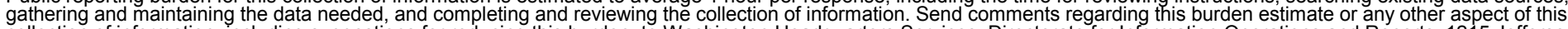

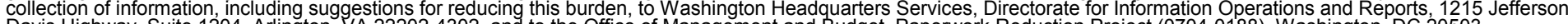

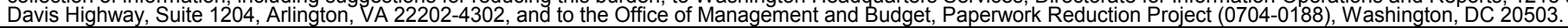

\begin{tabular}{|l|l|l} 
1. AGENCY USE ONLY (Leave blank) & $\begin{array}{c}\text { 2. REPORT DATE } \\
\text { November } 1999\end{array}$ & $\begin{array}{l}\text { 3. REPORT TYPE AND DATES COVERED } \\
\text { Subcontract Report }\end{array}$ \\
\hline
\end{tabular}

\section{TITLE AND SUBTITLE}

The Value of the Benefits of U.S. Biomass Power

6. AUTHOR(S)

G. Morris

\section{PERFORMING ORGANIZATION NAME(S) AND ADDRESS(ES)}

Green Power Institute

Berkeley, CA

\section{SPONSORING/MONITORING AGENCY NAME(S) AND ADDRESS(ES)}

National Renewable Energy Laboratory

1617 Cole Boulevard

Golden, CO 80401-3393

8. PERFORMING ORGANIZATION REPORT NUMBER

\section{SPONSORING/MONITORING} AGENCY REPORT NUMBER

NREL/SR-570-27541

\section{SUPPLEMENTARY NOTES}

Technical Monitor: Richard Bain

12a. DISTRIBUTION/AVAILABILITY STATEMENT

National Technical Information Service

U.S. Department of Commerce

5285 Port Royal Road

Springfield, VA 22161

13. ABSTRACT (Maximum 200 words) Biomass power has always been used to generate power in the forest products industry, but its widespread use for supplying power to the U.S. grid is a relatively recent phenomenon. Today independent biomass power generators supply 11 billion $\mathrm{kWh} / \mathrm{yr}$ to the national electricity grid and, in the process, provide an environmentally superior disposal service for 22 million tons/yr of solid waste

\section{SUBJECT TERMS}

biomass energy, power, electricity

\begin{tabular}{|c|c|c|}
\hline $\begin{array}{l}\text { 17. SECURITY CLASSIFICATION } \\
\text { OF REPORT }\end{array}$ & $\begin{array}{l}\text { 18. SECURITY CLASSIFICATION } \\
\text { OF THIS PAGE }\end{array}$ & $\begin{array}{l}\text { 19. SECURITY CLASSIFICATION } \\
\text { OF ABSTRACT }\end{array}$ \\
\hline
\end{tabular}

NSN 7540-01-280-5500 12b. DISTRIBUTION CODE
15. NUMBER OF PAGES

16. PRICE CODE

20. LIMITATION OF ABSTRACT

Standard Form 298 (Rev. 2-89) Prescribed by ANSI Std. Z39-18 